Perspective

\title{
Why is NMNAT Protective against Neuronal Cell Death and Axon Degeneration, but Inhibitory of Axon Regeneration?
}

\author{
Bor Luen Tang ${ }^{1,2}$ (1) \\ 1 Department of Biochemistry, Yong Loo Lin School of Medicine, National University of Singapore, \\ Singapore 117597, Singapore; bchtbl@nus.edu.sg; Tel.: +65-6516-1040 \\ 2 NUS Graduate School for Integrative Sciences and Engineering, National University of Singapore, \\ Singapore 117597, Singapore
}

Received: 3 March 2019; Accepted: 18 March 2019; Published: 21 March 2019

\begin{abstract}
Nicotinamide mononucleotide adenylyltransferase (NMNAT), a key enzyme for NAD ${ }^{+}$ synthesis, is well known for its activity in neuronal survival and attenuation of Wallerian degeneration. Recent investigations in invertebrate models have, however, revealed that NMNAT activity negatively impacts upon axon regeneration. Overexpression of Nmnat in laser-severed Drosophila sensory neurons reduced axon regeneration, while axon regeneration was enhanced in injured mechanosensory axons in C. elegans nmat-2 null mutants. These diametrically opposite effects of NMNAT orthologues on neuroprotection and axon regeneration appear counterintuitive as there are many examples of neuroprotective factors that also promote neurite outgrowth, and enhanced neuronal survival would logically facilitate regeneration. We suggest here that while NMNAT activity and $\mathrm{NAD}^{+}$production activate neuroprotective mechanisms such as SIRT1-mediated deacetylation, the same mechanisms may also activate a key axonal regeneration inhibitor, namely phosphatase and tensin homolog (PTEN). SIRT1 is known to deacetylate and activate PTEN which could, in turn, suppress PI3 kinase-mTORC1-mediated induction of localized axonal protein translation, an important process that determines successful regeneration. Strategic tuning of Nmnat activity and $\mathrm{NAD}^{+}$production in axotomized neurons may thus be necessary to promote initial survival without inhibiting subsequent regeneration.
\end{abstract}

Keywords: axon regeneration; neuroprotection; nicotinamide mononucleotide adenylyltransferase (NMNAT); nicotinamide adenine dinucleotide $\left(\mathrm{NAD}^{+}\right)$; phosphatase and tensin homolog (PTEN); SIRT1

\section{Introduction}

Nicotinamide mononucleotide adenylyltransferase (NMNAT) is an evolutionarily conserved rate-limiting enzyme that catalyzes the salvage pathway biosynthesis of the essential coenzyme nicotinamide adenine dinucleotide $\left(\mathrm{NAD}^{+}\right)$from ATP and nicotinamide mononucleotide (NMN) [1] Humans have three NMNAT paralogues, where NMNAT1 (predominantly nuclear) and NMNAT3 (mitochondrial and cytoplasmic depending on splice variant) are more ubiquitously expressed, while NMNT2 (cytoplasmic) is enriched in brain [2-4]. NMNATs, as NAD ${ }^{+}$synthases, have critical roles in energy metabolism. NMNAT is also a stress- and injury-induced protein $[5,6]$ and plays a particularly critical role in the maintenance of neuronal survival and health $[3,7,8]$. Loss of NMNAT2 in mice resulted in perinatal lethality with severe defects in peripheral nerves and regions of the central nervous system (CNS) [9]. In fact, adequate levels of NMNAT2 appear to be critical for axon development and survival, since NNMAT2 compound heterozygote mice present early and 
age-dependent peripheral nerve axonal defects [10]. Mutations in NMNAT1 in humans underlie the eye disorder Leber congenital amaurosis, which is characterized by patients suffering from early severe macular and optic atrophy [11]. In mice, overexpression of NMNAT1 protects both retinal ganglion cells and axons from glaucomatous and ischemic injury [12]. NMNAT-produced NAD ${ }^{+}$has indeed been identified as a key factor that determines neuronal survival and degeneration upon insult or injury $[13,14]$. NMNAT and its regulation of $\mathrm{NAD}^{+}$metabolism also have broader implications in terms of organismal level metabolic health and life span [15].

Axon regeneration upon injury is much more difficult in CNS neurons compared to peripheral neurons and is influenced by both external inhibitory factors within the injury environment [16], as well as by neuronal intrinsic factors and mechanisms $[17,18]$. Important intrinsic processes that facilitate axon regeneration include proper axonal mRNA localization, as well as adequate injury-induced local protein synthesis [19,20] and turnover [21]. In this regard, the mechanistic target of rapamycin (mTOR) [22] functions as a master regulator whose activation enhances mRNA translation and protein synthesis at the soma, as well as locally in the axon [23]. The activity of mTOR in association with the two signaling complexes in which mTOR integral part of, namely mTORC1 and mTORC2, is regulated by a complex interplay between the inhibitory tuberous sclerosis complex (TSC) family of proteins and the activating phosphoinositide 3 kinase-AKT kinase (PI3K-AKT) axis [24]. Another important player in this network is phosphatase and tensin homologue (PTEN) [25], a lipid phosphatase that antagonizes PI3K-AKT and, thus, negatively regulates mTOR signaling. PTEN is a key intrinsic inhibitor of axon regeneration, and its deletion or silencing promote regeneration of both adult peripheral neurons [26] and CNS neurons [27-31]. In this study, mTOR activity was conversely shown to promote axon regeneration by multiple neuron types [32-36]. In view of the critical and central roles played by mTOR and PTEN in axon regeneration, the action of many factors that influence the regeneration outcome would likely impinge on, or converge upon, these two molecules.

Although NMNAT is widely perceived as being critical for protection against neuronal death and degeneration, its direct influence on axon regeneration has been less clear. Recent evidence has, in fact, indicated that instead of a positive enhancement, NMNAT actually inhibits axon regeneration. In the paragraphs below, NMNAT's known neuroprotective and anti-degenerative actions shall be briefly recapped, and recent evidence for it acting as an inhibitor of axon regeneration recounted. Plausible explanations as to why NMNAT could be neuroprotective while inhibitory of axon regeneration shall then be expounded.

\section{NMNAT Has Important Neuroprotective Functions and Attenuates Wallerian Degeneration}

There is much evidence to support the notion that NMNAT and its product NAD ${ }^{+}$have key neuronal maintenance and protective functions [3,4], both during acute neuronal injury as well as in the context of neurodegenerative diseases. Other than the neuroprotective examples mentioned above, degeneration of dorsal root ganglion axons induced by rotenone, which inhibits mitochondrial electron transport and causes oxidative stresses, is delayed by NMNAT overexpression [5]. In a yeast model of proteinopathy, overexpression of the yeast homologues of NMNAT suppressed the cytotoxicity of aggregation-prone and neurodegeneration-associated polyglutamine-containing polypeptides and $\alpha$-synuclein [37]. NMNAT2 is found to be downregulated prior to the onset of neurodegeneration, and its overexpression is both neuroprotective [38] and alleviates behavioral impairments [39] in mouse models of tauopathy. In this regard, NMNAT was also shown to suppress tau-induced neurodegeneration by promoting the clearance of hyperphosphorylated tau oligomers in a Drosophila tauopathy model [40]. In the Wobbler mice motor neuron disease model, NMNAT2 levels in the spinal cord were found to be downregulated [41]. NMNATs, particularly the brain-enriched isoform NMNAT2, thus appear to be suppressive of multiple neurotoxic agents that promote neuronal degeneration.

As far as neuronal injury is concerned, a particularly important activity of NMNAT is its attenuation of Wallerian degeneration (WD) [42]. This was first demonstrated by mice with a 
remarkable post-injury retardation in $\mathrm{WD}$, where the underlying protective mutant gene Wallerian degeneration slow $\left(W l d^{s}\right)$ encodes a fusion protein of the $\mathrm{N}$-terminal fragment of ubiquitination factor E4B (Ube4b) to NMNAT [43]. The NMNAT enzyme activity of the WldS protein appears to be necessary for the WD retardation phenotype [44,45]. More recent studies have delineated the role of the pro-degenerative Sterile-alpha and Armadillo motif containing protein 1 (SARM1) in WD [46]. SARM1 is required for injury-induced WD as well as axonal death by enhancing axonal NAD ${ }^{+}$ depletion $[14,47,48]$, and SARM1 deficiency alleviated developmental defects and promoted survival of NMNAT2-deficient neurons [49]. Axon degeneration by injured neurons could, in fact, be blocked by NMNAT proteins that are directly transduced into transected axons [50]. NMNAT2 appears to be a labile molecule with a short half-life [7]. Maintaining a threshold level of NMNAT2 is, therefore, important for the prevention of spontaneous degeneration of healthy axons. In fact, NMNAT2 depletion alone appeared sufficient to induce WD-like features in uninjured axons, and degeneration could not be overcome by the presence of both NMNAT1 and NMNAT3 [7].

There is evidence that NMNAT's neuroprotective function is not limited to its enzymatic activity in producing $\mathrm{NAD}^{+}[51,52]$. NMNAT expression [6,52] and splicing [53] are stress-induced, and its neuroprotective action may be dependent on chaperone-like activity [4]. Some findings have indicated that while NMNAT's enzymatic activity is necessary for neuroprotection [44,54], the resulting increase in $\mathrm{NAD}^{+}$is not [54]. In fact, NMNAT1 has been shown to inhibit axon degeneration by directly blocking injury-induced and SARM1-dependent NAD ${ }^{+}$destruction [55]. NMNAT could thus exerts its neuroprotective functions in different ways which could potentially compliment, or even reinforce one other.

\section{NMNAT Inhibits Axon Regeneration in Two Invertebrate Models}

Despite the overwhelming evidence for a beneficial effect for NMNAT activity in neuronal survival and attenuation of axon degeneration upon injury, two recent studies in invertebrate models have indicated that NMNAT inhibits axon regeneration. The first is reported by Chen et al. [56] based on findings in a Drosophila sensory neuron preconditioning injury model [57] in which axon injury 'stabilizes' the cell, including the entire dendritic arbor, from subsequent death and dendritic degeneration. This state of neuroprotection (NP) is accompanied by an upregulation of mitochondrial fission in dendrites and is negatively regulated by Drosophila caspases. NP is absolutely dependent on Nmnat, and overexpression of the latter was sufficient to induce a neuroprotective state. Interestingly, the authors found that Nmnat overexpression and reduction of the initiator caspase Dronc both inhibited axon regeneration. Likewise, Wlds has an inhibitory effect on regeneration. The basis for this Nmnat-mediated inhibition of regeneration, and whether it is dependent on $\mathrm{NAD}^{+}$, is unclear. However, the authors showed that the protective effect is cell autonomous through the expression of the Wlds protein in ddaC neurons, which are adjacent to ddaE neurons. The Wlds-expressing ddaC neurons formed persistent axonal stumps but did not reduce regeneration of neighboring wild-type ddaE neurons.

Using a Caenorhabditis elegans mechanosensory axon regeneration assay, Kim et al. [58] reported a genetic screen which identified, among others, the worm NMNAT orthologue NMAT-2 as an inhibitory protein for axon regeneration. Axon regrowth was enhanced in two independent nmat-2-null mutants (but not the null mutants of the paralogous nmat-1), as well as null mutants of another NAD ${ }^{+}$ synthesizing enzyme, the glutamine-dependent $\mathrm{NAD}^{+}$synthase QNS-1. An enzyme active site mutant of nmat-2 also displayed a similar phenotype, indicating that $\mathrm{NAD}^{+}$is an important mediator of the inhibitory effect. The phenotype of the nmat-2-null mutant is rescued by a single copy of the transgene under the endogenous promoter. Interestingly, however, individual expression of the transgene in the epidermis, intestine, or mechanosensory neurons could not rescue the phenotype, which was only reversed by a combined expression in all three tissues. The authors speculated that "NAD ${ }^{+}$might activate inhibitory factors in neurons and in surrounding tissues, which act together to repress the axon regenerative response" [58]. 


\section{Plausible Mechanistic Explanations for the Dichotomous Effects of NMNAT}

The above findings suggest NMNAT and its activity are inhibitory of axon regeneration, which appears to be somewhat counterintuitive and paradoxical. Many neurotrophic and neuronal growth factors are known to promote both neuronal survival and neurite extension. On the other hand, even if a pro-survival factor does not directly induce neurite outgrowth, it would be intuitive to assume that extended neuronal survival would likely lead to a better regenerative outcome. How could NMNAT's neuroprotective and inhibitory axon regeneration activities be reconciled?

There are some early observations which suggest that the NMNAT activity of Wlds does not promote, and may in fact retard, axon regeneration. Regeneration of sensory axons [59] and motor axons [60] are reportedly impaired in the degeneration-delayed C57BL/Ola mouse. WD appears to be necessary for proper zebrafish trigeminal axon regeneration and innervation of the epidermis after injury [61]. The increased neurite growth that normally occurs after a conditioning lesion of dorsal root ganglion neurons was also reduced in $W l d^{s}$ mice [62]. The process of axonal fragmentation in WD itself, and perhaps also the subsequent clearance of the fragments by immune cells, may therefore promote neurite or axonal outgrowth. On the other hand, regeneration in terms of polarized growth of another axon could be inhibited or delayed by the persistence of the degenerating axon.

There is also the possibility that NMNAT expression in injured neurons attenuates axon regeneration in a cell non-autonomous manner. A persistent axonal stump that is slow to degrade could conceivably prevent collateral sprouts. Indeed, in Wld ${ }^{s}$ mice, collateral sprouting from spared fibers after spinal cord injury was greatly reduced compared to wild-type mice, resulting in a worse locomotor recovery [63]. It is possible that NMNAT upregulates inhibitory factors, either soluble or membrane-bound, to attenuate collateral sprouting. However, this mode of action is not at work for the Drosophila model discussed above, where persistent stumps generated by a WldS-expressing neuron type did not reduce regeneration of different types of neighboring neurons the way NMNAT expression did.

We are, therefore, left to contemplate the possible cell autonomous mechanisms underlying the dichotomous action of NMNAT. The NAD ${ }^{+}$generated by NMNAT is an essential cofactor for two major classes of proteins known to be associated with neuronal survival and degeneration. The poly (ADP-ribose) polymerases (PARPs) are a family of proteins involved in DNA repair and are most often associated with acute neuronal death and neurodegenerative diseases [64-66]. It was recently reported that mutations of either of two C. elegans PARP homologs, parp-1 and parp-2, enhanced axon regeneration by injured GABA motor neurons in worms, and PARP silencing promoted axon regeneration of mouse cortical neurons [67]. Similar effects were demonstrated by PARP inhibitors [67]. However, another report showed that axon regeneration after optic nerve crush and spinal cord hemisection was not enhanced in PARP - / - mice, nor were they enhanced by treatment with the PARP inhibitor veliparib [68]. Thus, the role played by PARP in axon regeneration remains controversial.

On the other hand, we have the Sirtuin class III histone deacetylases, whose protein deacetylase activities are strictly dependent on $\mathrm{NAD}^{+}$[69]. Some members of this family, particularly SIRT1, are pro-survival for neurons [70,71], and could also act as a mediator of the delay in WD mediated by NMNAT-generated NAD ${ }^{+}[72,73]$. SIRT1 shuttles between the cytoplasm and the nucleus [74], and could suppress neuronal death triggered by multiple stimuli via its deacetylation of TP53 [75-77] and the forkhead family of transcription factors [78-80]. Several reports have indicated that SIRT1 promotes neurite outgrowth in cultured neural cells [81-83], axonogenesis of primary neurons [84] and sensory axon regeneration of adult DRG neurons [85]. However, apart from the latter example, the first two mentioned study subjects were implicated in normal healthy morphological, developmental differentiation, rather than regeneration of damaged, degenerated, or cut axons after injury. In C. elegans, sir-2.1 mutations did not significantly influence axon regeneration by injured GABA motor neurons, although transgenic overexpression of the Sirtuin substrate daf-16/FOXO did enhance axon regeneration [86]. 
Could SIRT1 activity actually suppress axon regeneration? As mentioned above, PTEN and mTOR are key regulators of axon regeneration [87]. Deletion of PTEN or upregulation of mTOR activity promoted regeneration even in CNS neurons [27-29]. Exactly how PTEN suppresses axon regeneration remains to be fully clarified, but this is likely connected to mTOR's role in nutrient homeostasis through regulating protein translation and autophagy [88]. Axonal mRNA transport and localized axonal protein translation appear to be particularly important determinants for successful regeneration $[20,21,89,90]$, and inhibition of these processes would retard regeneration.

PTEN, notably, is acetylated at lysine residues (Lys125 and Lys128) within its catalytic site by P300/CREB-binding protein (CBP) associated factor (PCAF) [91], which attenuates its catalytic activity. PTEN is also acetylated at Lys402 in a manner that is dependent on CBP, and this residue lies within its carboxyl terminal PDZ domain-binding motif [92]. On the other hand, SIRT1 has been shown to be a major PTEN deacetylase [92,93], and SIRT1 deacetylation would enhance PTEN's catalytic activity. It is, therefore, conceivable that SIRT1 activity, promoted by the NAD ${ }^{+}$produced by NMNAT, could be inhibitory of axon regeneration via an enhancement of local PTEN activity. A plausible explanation of how NMNAT-generated $\mathrm{NAD}^{+}$could protect against neuronal death and $\mathrm{WD}$, while inhibiting axon regeneration, is summarized schematically in Figure 1 below. In brief, the activation of PTEN by $\mathrm{NAD}^{+}$-dependent SIRT1 deacetylation, particularly within the axon, could impinge negatively on mTOR activity, thus leading to a reduction in localized axonal protein translation, thereby attenuating axon regeneration.

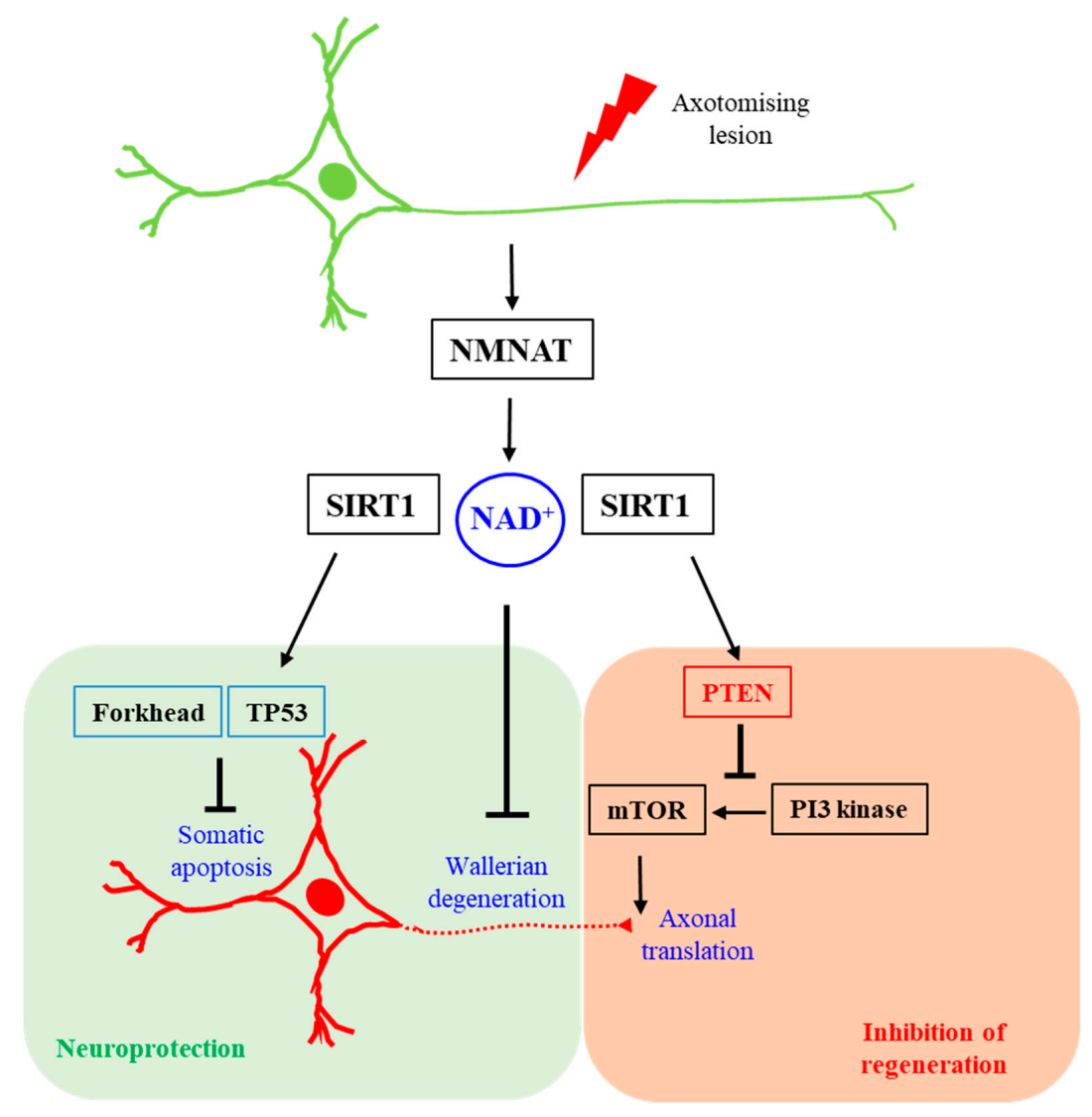

Figure 1. A schematic diagram illustrating how nicotinamide mononucleotide adenylyltransferase (NMNAT)-produced $\mathrm{NAD}^{+}$might be protective against neuronal death and axon degeneration and simultaneously inhibitory against axon regeneration. $\mathrm{NAD}^{+}$alleviates Wallerian degeneration and is a critical coenzyme of SIRT1. While SIRT1 deacetylation diminishes or modifies the death-inducing activities of TP53 and forkhead transcription factors, its deacetylation may activate the anti-axon regeneration factor PTEN, whose activity may negatively impact local axonal translation and protein turnover. 


\section{Perspectives}

The paragraphs above discussed recent research that supports the somewhat paradoxical observation that neuroprotective and WD-attenuating NMNAT expression or activity inhibits axon regeneration in Drosophila and C. elegans models of sensory neuron axotomy. While cell non-autonomous mechanisms could not be ruled out, a plausible cell autonomous mechanism that provides tentative explanations for the observations could be discerned. In particular, while NMNAT-produced NAD ${ }^{+}$enhanced SIRT1 deacetylation of proteins that suppressed cell death and WD, its deacetylation of PTEN could, on the other hand, inhibit axon regeneration. This notion can be tested by careful assessments of possible reciprocal changes in SIRT1 and PTEN activities in NMNAT-expressing or -deleted neurons, as well as in animal models engineered to express acetylation-resistant PTEN in neurons. Of course, $\mathrm{NAD}^{+}$is also important for the activities of other Sirtuin family members and, in this regard, cytoplasmic SIRT2-a major tubulin deacetylase [94] whose loss is associated with axonal degeneration [95] — would be of particular interest. A recent finding has also revealed that SIRT4 could interact with PTEN and regulate its stability in a manner that is independent of PTEN acetylation [96]. We have more to learn about how PTEN interacts with neuronal Sirtuins and how these affect its role in regeneration.

The above notion that SIRT1's deacetylation and activation of PTEN could inhibit axon regeneration is not without caveats and reservations. There are several notable issues, including earlier findings that $C$. elegans sir2.1 had little effect in axonal regeneration [86] and that SIRT1 inhibitor and its associated silencing both promoted DRG sensory axon regeneration [85]. The neuroprotective action of resveratrol, an allosteric activator of SIRT1 [97], is well known [98] and, in several cases, it has been demonstrated that it acts through SIRT1 in this regard [99,100]. Two recent reports have also indicated that resveratrol treatment promoted axon regeneration in different models [101,102]. Resveratrol has, however, a myriad of known cellular targets $[103,104]$, and in the above cases, its role in axon regeneration was attributed to other molecules rather than SIRT1 activation. A potential rejoinder for these reservations is that SIRT1 activity is both pro-survival and inhibitory of axonal degradation, and it could indirectly contribute towards regeneration at a later time. In other words, SIRT1 activity could have both an axon regeneration-promoting effect as well as an inhibitory effect, and the outcome depends on a balance between the two.

It should also be noted that the interacting pathways involved in axon regeneration could be very much context- and neuronal type-dependent, with optimal conditions for axon regeneration differing between neuron types, for example, CNS and peripheral nervous system (PNS) neurons, or between invertebrate and mammalian neurons. Furthermore, PTEN activation and attenuation of mTOR activity could induce autophagy. The latter process is generally neuroprotective but its over-activation could also lead to neuronal cell death [105]. Autophagy has been shown to negatively regulate axon extension by primary cortical neurons [106], and even different neuron types in one region, but its induction was also found to stabilize microtubules and promote axonal regeneration in a mouse spinal cord injury model $[107,108]$. The above notion of PTEN mediating the axon regeneration inhibitory effect of NMNAT could, thus, be an oversimplification. In reality, axon regeneration is a complex process that is dependent on the degree of injury, the extent of neuron sparing, the types of neuron involved, and various other factors. With regards to the possibility of species differences in axonal regeneration, the process of axonal fusion that occurs spontaneously in some invertebrate species [109] would enhance nerve repair in ways that are perhaps independent of NMNAT and PTEN.

The findings discussed above also suggest that administration of restorative or regenerative strategies in neuronal injury may require more sophistication than previously perceived. One would need to strike a balance between neuronal survival/degeneration and axon regeneration, which now appear to be processes that do not go hand in hand. At the moment, it is unclear if it is possible or even beneficial to tackle the two in a temporally segregated manner, with initial neuroprotective therapeutics replaced by pro-regenerative ones after an initial acute phase of injury. Again, in this regard, we have much more to explore and learn. 
Author Contributions: Conceptualization, B.L.T.; writing, review and editing, B.L.T.

Funding: This research received no external funding.

Acknowledgments: B.L.T. is supported by the NUS Graduate School for Integrative Sciences and Engineering (NGS) and the Office of Deputy President, Research \& Technology (ODPRT) of the National University of Singapore. He is grateful to the reviewers, whose constructive comments improved the manuscript.

Conflicts of Interest: The author declares no conflict of interest.

\section{References}

1. Jayaram, H.N.; Kusumanchi, P.; Yalowitz, J.A. NMNAT expression and its relation to NAD metabolism. Curr. Med. Chem. 2011, 18, 1962-1972. [CrossRef] [PubMed]

2. Lau, C.; Niere, M.; Ziegler, M. The NMN/NaMN adenylyltransferase (NMNAT) protein family. Front. Biosci. 2009, 14, 410-431. [CrossRef]

3. Ali, Y.O.; Li-Kroeger, D.; Bellen, H.J.; Zhai, R.G.; Lu, H.C. NMNATs, evolutionarily conserved neuronal maintenance factors. Trends Neurosci. 2013, 36, 632-640. [CrossRef] [PubMed]

4. Brazill, J.M.; Li, C.; Zhu, Y.; Zhai, R.G. NMNAT: It's an NAD+ synthase ... It's a chaperone ... It's a neuroprotector. Curr. Opin. Genet. Dev. 2017, 44, 156-162. [CrossRef] [PubMed]

5. Press, C.; Milbrandt, J. Nmnat delays axonal degeneration caused by mitochondrial and oxidative stress. J. Neurosci. 2008, 28, 4861-4871. [CrossRef]

6. Ali, Y.O.; McCormack, R.; Darr, A.; Zhai, R.G. Nicotinamide mononucleotide adenylyltransferase is a stress response protein regulated by the heat shock factor/hypoxia-inducible factor 1alpha pathway. J. Biol. Chem. 2011, 286, 19089-19099. [CrossRef]

7. Gilley, J.; Coleman, M.P. Endogenous Nmnat2 is an essential survival factor for maintenance of healthy axons. PLoS Biol. 2010, 8, e1000300. [CrossRef]

8. Pottorf, T.; Mann, A.; Fross, S.; Mansel, C.; Vohra, B.P.S. Nicotinamide Mononucleotide Adenylyltransferase 2 maintains neuronal structural integrity through the maintenance of golgi structure. Neurochem. Int. 2018, 121, 86-97. [CrossRef]

9. Gilley, J.; Adalbert, R.; Yu, G.; Coleman, M.P. Rescue of peripheral and CNS axon defects in mice lacking NMNAT2. J. Neurosci. 2013, 33, 13410-13424. [CrossRef]

10. Gilley, J.; Mayer, P.R.; Yu, G.; Coleman, M.P. Low levels of NMNAT2 compromise axon development and survival. Hum. Mol. Genet. 2019, 28, 448-458. [CrossRef]

11. Tsang, S.H.; Sharma, T. Leber Congenital Amaurosis. Adv. Exp. Med. Biol. 2018, 1085, 131-137.

12. Zhu, Y.; Zhang, L.; Sasaki, Y.; Milbrandt, J.; Gidday, J.M. Protection of mouse retinal ganglion cell axons and soma from glaucomatous and ischemic injury by cytoplasmic overexpression of Nmnat1. Invest. Ophthalmol. Vis. Sci. 2013, 54, 25-36. [CrossRef]

13. Alano, C.C.; Garnier, P.; Ying, W.; Higashi, Y.; Kauppinen, T.M.; Swanson, R.A. NAD+ depletion is necessary and sufficient for poly(ADP-ribose) polymerase-1-mediated neuronal death. J. Neurosci. 2010, 30, 2967-2978. [CrossRef]

14. Gerdts, J.; Brace, E.J.; Sasaki, Y.; DiAntonio, A.; Milbrandt, J. SARM1 activation triggers axon degeneration locally via NAD ${ }^{+}$destruction. Science 2015, 348, 453-457. [CrossRef]

15. Imai, S.I.; Guarente, L. NAD+ and sirtuins in aging and disease. Trends Cell Biol. 2014, 24, 464-471. [CrossRef] [PubMed]

16. Geoffroy, C.G.; Zheng, B. Myelin-associated inhibitors in axonal growth after CNS injury. Curr. Opin. Neurobiol. 2014, 27, 31-38. [CrossRef] [PubMed]

17. He, Z.; Jin, Y. Intrinsic control of axon regeneration. Neuron 2016, 90, 437-451. [CrossRef]

18. Mahar, M.; Cavalli, V. Intrinsic mechanisms of neuronal axon regeneration. Nat. Rev. Neurosci. $2018,1$. [CrossRef] [PubMed]

19. Jung, H.; Yoon, B.C.; Holt, C.E. Axonal mRNA localization and local protein synthesis in nervous system assembly, maintenance and repair. Nat. Rev. Neurosci. 2012, 13, 308-324. [CrossRef] [PubMed]

20. Koley, S.; Rozenbaum, M.; Fainzilber, M.; Terenzio, M. Translating regeneration: Local protein synthesis in the neuronal injury response. Neurosci Res. 2019, 139, 26-36. [CrossRef] [PubMed] 
21. Verma, P.; Chierzi, S.; Codd, A.M.; Campbell, D.S.; Meyer, R.L.; Holt, C.E.; Fawcett, J.W. Axonal protein synthesis and degradation are necessary for efficient growth cone regeneration. J. Neurosci. 2005, 25, 331-342. [CrossRef]

22. Switon, K.; Kotulska, K.; Janusz-Kaminska, A.; Zmorzynska, J.; Jaworski, J. Molecular neurobiology of mTOR. Neuroscience 2017, 341, 112-153. [CrossRef] [PubMed]

23. Terenzio, M.; Koley, S.; Samra, N.; Rishal, I.; Zhao, Q.; Sahoo, P.K.; Urisman, A.; Marvaldi, L.; Oses-Prieto, J.A.; Forester, C.; et al. Locally translated mTOR controls axonal local translation in nerve injury. Science 2018, 359, 1416-1421. [CrossRef] [PubMed]

24. Huang, J.; Manning, B.D. A complex interplay between Akt, TSC2 and the two mTOR complexes. Biochem. Soc. Trans. 2009, 37, 217-222. [CrossRef]

25. Worby, C.A.; Dixon, J.E. PTEN. Annu. Rev. Biochem. 2014, 83, 641-669. [CrossRef] [PubMed]

26. Christie, K.J.; Webber, C.A.; Martinez, J.A.; Singh, B.; Zochodne, D.W. PTEN inhibition to facilitate intrinsic regenerative outgrowth of adult peripheral axons. J. Neurosci. 2010, 30, 9306-9315. [CrossRef] [PubMed]

27. Park, K.K.; Liu, K.; Hu, Y.; Smith, P.D.; Wang, C.; Cai, B.; Xu, B.; Connolly, L.; Kramvis, I.; Sahin, M.; et al. Promoting axon regeneration in the adult CNS by modulation of the PTEN/mTOR pathway. Science 2008, 322, 963-966. [CrossRef]

28. Liu, K.; Lu, Y.; Lee, J.K.; Samara, R.; Willenberg, R.; Sears-Kraxberger, I.; Tedeschi, A.; Park, K.K.; Jin, D.; Cai, B.; et al. PTEN deletion enhances the regenerative ability of adult corticospinal neurons. Nat. Neurosci. 2010, 13, 1075-1081. [CrossRef]

29. Sun, F.; Park, K.K.; Belin, S.; Wang, D.; Lu, T.; Chen, G.; Zhang, K.; Yeung, C.; Feng, G.; Yankner, B.A.; et al. Sustained axon regeneration induced by co-deletion of PTEN and SOCS3. Nature 2011, 480, 372-375. [CrossRef]

30. Zukor, K.; Belin, S.; Wang, C.; Keelan, N.; Wang, X.; He, Z. Short hairpin RNA against PTEN enhances regenerative growth of corticospinal tract axons after spinal cord injury. J. Neurosci. 2013, 33, 15350-15361. [CrossRef]

31. Du, K.; Zheng, S.; Zhang, Q.; Li, S.; Gao, X.; Wang, J.; Jiang, L.; Liu, K. Pten Deletion Promotes Regrowth of Corticospinal Tract Axons 1 Year after Spinal Cord Injury. J. Neurosci. 2015, 35, 9754-9763. [CrossRef]

32. Abe, N.; Borson, S.H.; Gambello, M.J.; Wang, F.; Cavalli, V. Mammalian target of rapamycin (mTOR) activation increases axonal growth capacity of injured peripheral nerves. J. Biol. Chem. 2010, 285, 28034-28043. [CrossRef] [PubMed]

33. Cho, Y.; Di Liberto, V.; Carlin, D.; Abe, N.; Li, K.H.; Burlingame, A.L.; Guan, S.; Michaelevski, I.; Cavalli, V. Syntaxin13 expression is regulated by mammalian target of rapamycin (mTOR) in injured neurons to promote axon regeneration. J. Biol. Chem. 2014, 289, 15820-15832. [CrossRef] [PubMed]

34. Liu, Y.; Kelamangalath, L.; Kim, H.; Han, S.B.; Tang, X.; Zhai, J.; Hong, J.W.; Lin, S.; Son, Y.J.; Smith, G.M. NT-3 promotes proprioceptive axon regeneration when combined with activation of the mTor intrinsic growth pathway but not with reduction of myelin extrinsic inhibitors. Exp. Neurol. 2016, 283, 73-84. [CrossRef] [PubMed]

35. Chen, W.; Lu, N.; Ding, Y.; Wang, Y.; Chan, L.T.; Wang, X.; Gao, X.; Jiang, S.; Liu, K. Rapamycin-Resistant mTOR Activity Is Required for Sensory Axon Regeneration Induced by a Conditioning Lesion. Eneuro 2016, 3. [CrossRef] [PubMed]

36. Tassew, N.G.; Charish, J.; Shabanzadeh, A.P.; Luga, V.; Harada, H.; Farhani, N.; D'Onofrio, P.; Choi, B.; Ellabban, A.; Nickerson, P.E.B.; et al. Exosomes mediate mobilization of autocrine Wnt10b to promote axonal regeneration in the injured CNS. Cell Rep. 2017, 20, 99-111. [CrossRef] [PubMed]

37. Ocampo, A.; Liu, J.; Barrientos, A. NAD+ salvage pathway proteins suppress proteotoxicity in yeast models of neurodegeneration by promoting the clearance of misfolded/oligomerized proteins. Hum. Mol. Genet. 2013, 22, 1699-1708. [CrossRef] [PubMed]

38. Ljungberg, M.C.; Ali, Y.O.; Zhu, J.; Wu, C.S.; Oka, K.; Zhai, R.G.; Lu, H.C. CREB-activity and nmnat2 transcription are down-regulated prior to neurodegeneration, while NMNAT2 over-expression is neuroprotective, in a mouse model of human tauopathy. Hum. Mol. Genet. 2012, 21, 251-267. [CrossRef]

39. Rossi, F.; Geiszler, P.C.; Meng, W.; Barron, M.R.; Prior, M.; Herd-Smith, A.; Loreto, A.; Lopez, M.Y.; Faas, H.; Pardon, M.C.; et al. NAD-biosynthetic enzyme NMNAT1 reduces early behavioral impairment in the htau mouse model of tauopathy. Behav. Brain Res. 2018, 339, 140-152. [CrossRef] 
40. Ali, Y.O.; Ruan, K.; Zhai, R.G. NMNAT suppresses tau-induced neurodegeneration by promoting clearance of hyperphosphorylated tau oligomers in a Drosophila model of tauopathy. Hum. Mol. Genet. 2012, 21, 237-250. [CrossRef]

41. Röderer, P.; Klatt, L.; John, F.; Theis, V.; Winklhofer, K.F.; Theiss, C.; Matschke, V. Increased ROS level in spinal cord of Wobbler mice due to Nmnat2 downregulation. Mol. Neurobiol. 2018, 55, 8414-8424. [CrossRef]

42. Conforti, L.; Gilley, J.; Coleman, M.P. Wallerian degeneration: An emerging axon death pathway linking injury and disease. Nat. Rev. Neurosci. 2014, 15, 394-409. [CrossRef]

43. Mack, T.G.; Reiner, M.; Beirowski, B.; Mi, W.; Emanuelli, M.; Wagner, D.; Thomson, D.; Gillingwater, T.; Court, F.; Conforti, L.; et al. Wallerian degeneration of injured axons and synapses is delayed by a Ube4b/Nmnat chimeric gene. Nat. Neurosci. 2001, 4, 1199-1206. [CrossRef] [PubMed]

44. Jia, H.; Yan, T.; Feng, Y.; Zeng, C.; Shi, X.; Zhai, Q. Identification of a critical site in Wld(s): Essential for Nmnat enzyme activity and axon-protective function. Neurosci. Lett. 2007, 413, 46-51. [CrossRef] [PubMed]

45. Conforti, L.; Wilbrey, A.; Morreale, G.; Janeckova, L.; Beirowski, B.; Adalbert, R.; Mazzola, F.; Di Stefano, M.; Hartley, R.; Babetto, E.; et al. Wld S protein requires Nmnat activity and a short N-terminal sequence to protect axons in mice. J. Cell Biol. 2009, 184, 491-500. [CrossRef]

46. Gerdts, J.; Summers, D.W.; Milbrandt, J.; DiAntonio, A. Axon Self-Destruction: New Links among SARM1, MAPKs, and NAD+ Metabolism. Neuron 2016, 89, 449-460. [CrossRef] [PubMed]

47. Osterloh, J.M.; Yang, J.; Rooney, T.M.; Fox, A.N.; Adalbert, R.; Powell, E.H.; Sheehan, A.E.; Avery, M.A.; Hackett, R.; Logan, M.A.; et al. dSarm/Sarm1 is required for activation of an injury-induced axon death pathway. Science 2012, 337, 481-484. [CrossRef] [PubMed]

48. Summers, D.W.; Gibson, D.A.; DiAntonio, A.; Milbrandt, J. SARM1-specific motifs in the TIR domain enable NAD+ loss and regulate injury-induced SARM1 activation. Proc. Natl. Acad. Sci. USA. 2016, 113, E6271-E6280. [CrossRef] [PubMed]

49. Gilley, J.; Orsomando, G.; Nascimento-Ferreira, I.; Coleman, M.P. Absence of SARM1 rescues development and survival of NMNAT2-deficient axons. Cell Rep. 2015, 10, 1974-1981. [CrossRef]

50. Sasaki, Y.; Milbrandt, J. Axonal degeneration is blocked by nicotinamide mononucleotide adenylyltransferase (Nmnat) protein transduction into transected axons. J. Biol. Chem. 2010, 285, 41211-41215. [CrossRef]

51. Zhai, R.G.; Cao, Y.; Hiesinger, P.R.; Zhou, Y.; Mehta, S.Q.; Schulze, K.L.; Verstreken, P.; Bellen, H.J. Drosophila NMNAT maintains neural integrity independent of its NAD synthesis activity. PLoS Biol. 2006, 4, e416. [CrossRef] [PubMed]

52. Zhai, R.G.; Zhang, F.; Hiesinger, P.R.; Cao, Y.; Haueter, C.M.; Bellen, H.J. NAD synthase NMNAT acts as a chaperone to protect against neurodegeneration. Nature 2008, 452, 887-891. [CrossRef]

53. Ruan, K.; Zhu, Y.; Li, C.; Brazill, J.M.; Zhai, R.G. Alternative splicing of Drosophila Nmnat functions as a switch to enhance neuroprotection under stress. Nat. Commun. 2015, 6, 10057. [CrossRef] [PubMed]

54. Sasaki, Y.; Vohra, B.P.S.; Lund, F.E.; Milbrandt, J. Nicotinamide mononucleotide adenylyl transferase-mediated axonal protection requires enzymatic activity but not increased levels of neuronal nicotinamide adenine dinucleotide. J. Neurosci. 2009, 29, 5525-5535. [CrossRef]

55. Sasaki, Y.; Nakagawa, T.; Mao, X.; DiAntonio, A.; Milbrandt, J. NMNAT1 inhibits axon degeneration via blockade of SARM1-mediated NAD+ depletion. eLife 2016, 5, e19749. [CrossRef]

56. Chen, L.; Nye, D.M.; Stone, M.C.; Weiner, A.T.; Gheres, K.W.; Xiong, X.; Collins, C.A.; Rolls, M.M. Mitochondria and caspases tune Nmnat-mediated stabilization to promote axon regeneration. PLoS Genet. 2016, 12, e1006503. [CrossRef] [PubMed]

57. Chen, L.; Stone, M.C.; Tao, J.; Rolls, M.M. Axon injury and stress trigger a microtubule-based neuroprotective pathway. Proc. Natl. Acad. Sci. USA. 2012, 109, 11842-11847. [CrossRef]

58. Kim, K.W.; Tang, N.H.; Piggott, C.A.; Andrusiak, M.G.; Park, S.; Zhu, M.; Kurup, N.; Cherra, S.J.; Wu, Z.; Chisholm, A.D.; et al. Expanded genetic screening in Caenorhabditis elegans identifies new regulators and an inhibitory role for NAD+ in axon regeneration. eLife 2018, 7, e39756. [CrossRef]

59. Bisby, M.A.; Chen, S. Delayed wallerian degeneration in sciatic nerves of C57BL/Ola mice is associated with impaired regeneration of sensory axons. Brain Res. 1990, 530, 117-120. [CrossRef]

60. Chen, S.; Bisby, M.A. Impaired motor axon regeneration in the C57BL/Ola mouse. J. Comp. Neurol. 1993, 333, 449-454. [CrossRef] 
61. Martin, S.M.; O’Brien, G.S.; Portera-Cailliau, C.; Sagasti, A. Wallerian degeneration of zebrafish trigeminal axons in the skin is required for regeneration and developmental pruning. Development 2010, 137, 3985-3994. [CrossRef] [PubMed]

62. Niemi, J.P.; DeFrancesco-Lisowitz, A.; Roldán-Hernández, L.; Lindborg, J.A.; Mandell, D.; Zigmond, R.E. A critical role for macrophages near axotomized neuronal cell bodies in stimulating nerve regeneration. J. Neurosci. 2013, 33, 16236-16248. [CrossRef] [PubMed]

63. Collyer, E.; Catenaccio, A.; Lemaitre, D.; Diaz, P.; Valenzuela, V.; Bronfman, F.; Court, F.A. Sprouting of axonal collaterals after spinal cord injury is prevented by delayed axonal degeneration. Exp. Neurol. 2014, 261, 451-461. [CrossRef] [PubMed]

64. Moroni, F. Poly(ADP-ribose)polymerase 1 (PARP-1) and postischemic brain damage. Curr. Opin. Pharmacol. 2008, 8, 96-103. [CrossRef] [PubMed]

65. Gerace, E.; Masi, A.; Resta, F.; Felici, R.; Landucci, E.; Mello, T.; Pellegrini-Giampietro, D.E.; Mannaioni, G.; Moroni, F. PARP-1 activation causes neuronal death in the hippocampal CA1 region by increasing the expression of $\mathrm{Ca}(2+)$-permeable AMPA receptors. Neurobiol. Dis. 2014, 70, 43-52. [CrossRef] [PubMed]

66. Narne, P.; Pandey, V.; Simhadri, P.K.; Phanithi, P.B. Poly(ADP-ribose)polymerase-1 hyperactivation in neurodegenerative diseases: The death knell tolls for neurons. Semin. Cell Dev. Biol. 2017, 63, 154-166. [CrossRef] [PubMed]

67. Byrne, A.B.; McWhirter, R.D.; Sekine, Y.; Strittmatter, S.M.; Miller, D.M.; Hammarlund, M. Inhibiting poly(ADP-ribosylation) improves axon regeneration. eLife 2016, 5. [CrossRef] [PubMed]

68. Wang, X.; Sekine, Y.; Byrne, A.B.; Cafferty, W.B.J.; Hammarlund, M.; Strittmatter, S.M. Inhibition of poly-ADP-ribosylation fails to increase axonal regeneration or improve functional recovery after adult mammalian CNS injury. Eneuro 2016, 3. [CrossRef]

69. Blander, G.; Guarente, L. The Sir2 family of protein deacetylases. Annu. Rev. Biochem. 2004, 73, 417-435. [CrossRef]

70. Xu, J.; Jackson, C.W.; Khoury, N.; Escobar, I.; Perez-Pinzon, M.A. Brain SIRT1 mediates metabolic homeostasis and neuroprotection. Front. Endocrinol. 2018, 9, 702. [CrossRef]

71. Ng, F.; Wijaya, L.; Tang, B.L. SIRT1 in the brain-connections with aging-associated disorders and lifespan. Front. Cell Neurosci. 2015, 9, 64. [CrossRef] [PubMed]

72. Araki, T.; Sasaki, Y.; Milbrandt, J. Increased nuclear NAD biosynthesis and SIRT1 activation prevent axonal degeneration. Science 2004, 305, 1010-1013. [CrossRef]

73. Calliari, A.; Bobba, N.; Escande, C.; Chini, E.N. Resveratrol delays Wallerian degeneration in a NAD (+) and DBC1 dependent manner. Exp. Neurol. 2014, 251, 91-100. [CrossRef]

74. Tanno, M.; Sakamoto, J.; Miura, T.; Shimamoto, K.; Horio, Y. Nucleocytoplasmic shuttling of the NAD+-dependent histone deacetylase SIRT1. J. Biol. Chem. 2007, 282, 6823-6832. [CrossRef] [PubMed]

75. Luo, J.; Nikolaev, A.Y.; Imai, S.; Chen, D.; Su, F.; Shiloh, A.; Guarente, L.; Gu, W. Negative control of p53 by Sir2alpha promotes cell survival under stress. Cell 2001, 107, 137-148. [CrossRef]

76. Langley, E.; Pearson, M.; Faretta, M.; Bauer, U.M.; Frye, R.A.; Minucci, S.; Pelicci, P.G.; Kouzarides, T. Human SIR2 deacetylates p53 and antagonizes PML/p53-induced cellular senescence. EMBO J. 2002, 21, 2383-2396. [CrossRef]

77. Vaziri, H.; Dessain, S.K.; Ng Eaton, E.; Imai, S.I.; Frye, R.A.; Pandita, T.K.; Guarente, L.; Weinberg, R.A. hSIR2(SIRT1) functions as an NAD-dependent p53 deacetylase. Cell 2001, 107, 149-159. [CrossRef]

78. Motta, M.C.; Divecha, N.; Lemieux, M.; Kamel, C.; Chen, D.; Gu, W.; Bultsma, Y.; McBurney, M.; Guarente, L. Mammalian SIRT1 represses forkhead transcription factors. Cell 2004, 116, 551-563. [CrossRef]

79. Yang, Y.; Hou, H.; Haller, E.M.; Nicosia, S.V.; Bai, W. Suppression of FOXO1 activity by FHL2 through SIRT1-mediated deacetylation. EMBO J. 2005, 24, 1021-1032. [CrossRef] [PubMed]

80. Brunet, A.; Sweeney, L.B.; Sturgill, J.F.; Chua, K.F.; Greer, P.L.; Lin, Y.; Tran, H.; Ross, S.E.; Mostoslavsky, R.; Cohen, H.Y.; et al. Stress-dependent regulation of FOXO transcription factors by the SIRT1 deacetylase. Science 2004, 303, 2011-2015. [CrossRef] [PubMed]

81. Guo, W.; Qian, L.; Zhang, J.; Zhang, W.; Morrison, A.; Hayes, P.; Wilson, S.; Chen, T.; Zhao, J. Sirt1 overexpression in neurons promotes neurite outgrowth and cell survival through inhibition of the mTOR signaling. J. Neurosci. Res. 2011, 89, 1723-1736. [CrossRef] [PubMed]

82. Liu, Y.; Yao, Z.; Zhang, L.; Zhu, H.; Deng, W.; Qin, C. Insulin induces neurite outgrowth via SIRT1 in SH-SY5Y cells. Neuroscience 2013, 238, 371-380. [CrossRef] [PubMed] 
83. Sugino, T.; Maruyama, M.; Tanno, M.; Kuno, A.; Houkin, K.; Horio, Y. Protein deacetylase SIRT1 in the cytoplasm promotes nerve growth factor-induced neurite outgrowth in PC12 cells. FEBS Lett. 2010, 584, 2821-2826. [CrossRef] [PubMed]

84. Li, X.H.; Chen, C.; Tu, Y.; Sun, H.T.; Zhao, M.L.; Cheng, S.X.; Qu, Y.; Zhang, S. Sirt1 promotes axonogenesis by deacetylation of Akt and inactivation of GSK3. Mol. Neurobiol. 2013, 48, 490-499. [CrossRef] [PubMed]

85. Liu, C.M.; Wang, R.Y.; Saijilafu; Jiao, Z.X.; Zhang, B.Y.; Zhou, F.Q. MicroRNA-138 and SIRT1 form a mutual negative feedback loop to regulate mammalian axon regeneration. Genes Dev. 2013, 27, 1473-1483. [CrossRef] [PubMed]

86. Byrne, A.B.; Walradt, T.; Gardner, K.E.; Hubbert, A.; Reinke, V.; Hammarlund, M. Insulin/IGF1 signaling inhibits age-dependent axon regeneration. Neuron 2014, 81, 561-573. [CrossRef]

87. Park, K.K.; Liu, K.; Hu, Y.; Kanter, J.L.; He, Z. PTEN/mTOR and axon regeneration. Exp. Neurol. 2010, 223, 45-50. [CrossRef] [PubMed]

88. Saxton, R.A.; Sabatini, D.M. mTOR signaling in growth, metabolism, and disease. Cell 2017, 168, 960-976. [CrossRef]

89. Kalinski, A.L.; Sachdeva, R.; Gomes, C.; Lee, S.J.; Shah, Z.; Houle, J.D.; Twiss, J.L. mRNAs and protein synthetic machinery localize into regenerating spinal cord axons when they are provided a substrate that supports growth. J. Neurosci. 2015, 35, 10357-10370. [CrossRef]

90. Tasdemir-Yilmaz, O.E.; Segal, R.A. There and back again: Coordinated transcription, translation and transport in axonal survival and regeneration. Curr. Opin. Neurobiol. 2016, 39, 62-68. [CrossRef]

91. Okumura, K.; Mendoza, M.; Bachoo, R.M.; DePinho, R.A.; Cavenee, W.K.; Furnari, F.B. PCAF modulates PTEN activity. J. Biol. Chem. 2006, 281, 26562-26568. [CrossRef] [PubMed]

92. Ikenoue, T.; Inoki, K.; Zhao, B.; Guan, K.L. PTEN acetylation modulates its interaction with PDZ domain. Cancer Res. 2008, 68, 6908-6912. [CrossRef] [PubMed]

93. Chae, H.D.; Broxmeyer, H.E. SIRT1 deficiency downregulates PTEN/JNK/FOXO1 pathway to block reactive oxygen species-induced apoptosis in mouse embryonic stem cells. Stem Cell. Dev. 2011, 20, 1277-1285. [CrossRef] [PubMed]

94. Inoue, T.; Hiratsuka, M.; Osaki, M.; Yamada, H.; Kishimoto, I.; Yamaguchi, S.; Nakano, S.; Katoh, M.; Ito, H.; Oshimura, M. SIRT2, a tubulin deacetylase, acts to block the entry to chromosome condensation in response to mitotic stress. Oncogene 2007, 26, 945-957. [CrossRef] [PubMed]

95. Fourcade, S.; Morató, L.; Parameswaran, J.; Ruiz, M.; Ruiz-Cortés, T.; Jové, M.; Naudí, A.; Martínez-Redondo, P.; Dierssen, M.; Ferrer, I.; et al. Loss of SIRT2 leads to axonal degeneration and locomotor disability associated with redox and energy imbalance. Aging Cell 2017, 16, 1404-1413. [CrossRef] [PubMed]

96. Liu, M.; Wang, Z.; Ren, M.; Yang, X.; Liu, B.; Qi, H.; Yu, M.; Song, S.; Chen, S.; Liu, L.; et al. SIRT4 regulates PTEN stability through IDE in response to cellular stresses. FASEB J. 2019. [CrossRef] [PubMed]

97. Hubbard, B.P.; Gomes, A.P.; Dai, H.; Li, J.; Case, A.W.; Considine, T.; Riera, T.V.; Lee, J.E.; Yen, S.; Lamming, D.W.; et al. Evidence for a common mechanism of SIRT1 regulation by allosteric activators. Science 2013, 339, 1216-1219. [CrossRef] [PubMed]

98. Pallàs, M.; Porquet, D.; Vicente, A.; Sanfeliu, C. Resveratrol: New avenues for a natural compound in neuroprotection. Curr. Pharm. Des. 2013, 19, 6726-6731. [CrossRef] [PubMed]

99. Guida, N.; Laudati, G.; Anzilotti, S.; Secondo, A.; Montuori, P.; Di Renzo, G.; Canzoniero, L.M.T.; Formisano, L. Resveratrol via sirtuin-1 downregulates RE1-silencing transcription factor (REST) expression preventing PCB-95-induced neuronal cell death. Toxicol. Appl. Pharmacol. 2015, 288, 387-398. [CrossRef] [PubMed]

100. Laudati, G.; Mascolo, L.; Guida, N.; Sirabella, R.; Pizzorusso, V.; Bruzzaniti, S.; Serani, A.; Di Renzo, G.; Canzoniero, L.M.T.; Formisano, L. Resveratrol treatment reduces the vulnerability of SH-SY5Y cells and cortical neurons overexpressing SOD1-G93A to Thimerosal toxicity through SIRT1/DREAM/PDYN pathway. Neurotoxicology 2019, 71, 6-15. [CrossRef]

101. Oda, H.; Ohta, S.; Ikeguchi, R.; Noguchi, T.; Kaizawa, Y.; Yurie, H.; Takeuchi, H.; Mitsuzawa, S.; Matsuda, S. Pretreatment of nerve grafts with resveratrol improves axonal regeneration following replantation surgery for nerve root avulsion injury in rats. Restor. Neurol. Neurosci. 2018, 36, 647-658. [CrossRef] 
102. Ding, Z.; Cao, J.; Shen, Y.; Zou, Y.; Yang, X.; Zhou, W.; Guo, Q.; Huang, C. Resveratrol promotes nerve regeneration via activation of $\mathrm{p} 300$ acetyltransferase-mediated VEGF signaling in a rat model of sciatic nerve crush injury. Front. Neurosci. 2018, 12, 341. [CrossRef]

103. Dasgupta, B.; Milbrandt, J. Resveratrol stimulates AMP kinase activity in neurons. Proc. Natl. Acad. Sci. USA. 2007, 104, 7217-7222. [CrossRef]

104. Park, S.J.; Ahmad, F.; Philp, A.; Baar, K.; Williams, T.; Luo, H.; Ke, H.; Rehmann, H.; Taussig, R.; Brown, A.L.; et al. Resveratrol ameliorates aging-related metabolic phenotypes by inhibiting cAMP phosphodiesterases. Cell 2012, 148, 421-433. [CrossRef]

105. Galluzzi, L.; Bravo-San Pedro, J.M.; Blomgren, K.; Kroemer, G. Autophagy in acute brain injury. Nat. Rev. Neurosci. 2016, 17, 467-484. [CrossRef]

106. Ban, B.K.; Jun, M.H.; Ryu, H.H.; Jang, D.J.; Ahmad, S.T.; Lee, J.A. Autophagy negatively regulates early axon growth in cortical neurons. Mol. Cell Biol. 2013, 33, 3907-3919. [CrossRef]

107. Yaku, K.; Okabe, K.; Nakagawa, T. NAD metabolism: Implications in aging and longevity. Ageing Res. Rev. 2018, 47, 1-17. [CrossRef]

108. He, M.; Ding, Y.; Chu, C.; Tang, J.; Xiao, Q.; Luo, Z.G. Autophagy induction stabilizes microtubules and promotes axon regeneration after spinal cord injury. Proc. Natl. Acad. Sci. USA. 2016, 113, 11324-11329. [CrossRef]

109. Neumann, B.; Linton, C.; Giordano-Santini, R.; Hilliard, M.A. Axonal fusion: An alternative and efficient mechanism of nerve repair. Prog. Neurobiol. 2019, 173, 88-101. [CrossRef]

(C) 2019 by the author. Licensee MDPI, Basel, Switzerland. This article is an open access article distributed under the terms and conditions of the Creative Commons Attribution (CC BY) license (http://creativecommons.org/licenses/by/4.0/). 